Pacific Journal of Mathematics

ON THE WEIERSTRASS POINTS ON OPEN RIEMANN 


\title{
ON THE WEIERSTRASS POINTS ON OPEN RIEMANN SURFACES
}

\author{
YUKIO HIRASHITA
}

The number of Weierstrass points on a compact Riemann surface of finite genus $g$ is at most $(g-1) g(g+1)$ and at least $2(g+1)$. After the Riemann-Roch's theorem for the class of canonical semi-exact differentials, Watanabe considered the number of Weierstrass points on an open Riemann surface of class $O_{K D}$. In this paper it will be shown that Watanabe's estimate can be proved without any conception of principal operators.

Using the notation and terminology of [1], the following theorem [6, Theorem 2] will be proved without use of the results of Mori [3], Rodin [4] and Royden [5]. Note that a meromorphic function on an open Riemann surface is said to be rational if Re $d f$ is distinguished.

THEOREM. Suppose that $R$ is a Riemann surface of finite genus $g$ on which $\Gamma_{h e} \cap \Gamma_{h s e}^{*} \subset \Gamma_{h e}^{*}$ holds. Then the number of Weierstrass points on $R$ is at most $(g-1) g(g+1)$.

Let $S$ be a compact continuation of $R$ such that the genus of $S$ is $g$. Suppose $P$ is a Weierstrass points on $R$ and $f$ is a rational function on $R$ which has the only singularity of order at most $g$ at

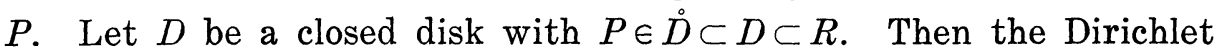
integral of $f$ over $R-D$ is finite. Since $\int_{\partial D} d \operatorname{Re} f^{*}=0$, there exist harmonic functions $u$ on $S-D$ and $v$ on $R$ such that $u-v=\operatorname{Re} f$ on $R-D$. Thus we have $d v \in \Gamma_{h e} \cap \Gamma_{h}^{*}$.

We wish to show that $d v^{*}$ is semi-exact on $R$. If $c$ is a dividing cycle on $R-D$, then $c$ is homologous to zero on $S-D$. This gives that

$$
\int_{c} d v^{*}=\int_{c} d u^{*}-\int_{c} d \operatorname{Im} f=0 .
$$

Since $d v \in \Gamma_{h e} \cap \Gamma_{h s e}^{*}$, it follows from the assumption that $d v^{*} \in \Gamma_{h e}$.

We define

$$
\lambda= \begin{cases}d u & \text { on } S-D \\ d v+d \operatorname{Re} f & \text { on } R .\end{cases}
$$

Then $\lambda$ and $\lambda^{*}$ have no periods along any cycle $b$ on $S$, where $b \nexists P$. Therefore $\int \lambda+i \lambda^{*}$ is a meromorphic function on $S$. It is easy to 
see that $\int \lambda+i \lambda^{*}$ has as its only singularity a pole of order at most $g$ at $P$. This shows that $P$ is a Weierstrass point on $S$. Due to the classical result on the Weierstrass points on compact Riemann surfaces our assertion is obtained.

\section{REFERENCES}

1. L. V. Ahlfors and L. Sario, Riemann Surfaces, Princeton, 1960.

2. A. Mori, A remark on the prolongation of Riemann surface of finite genus, J. Math. Soc. Japan, 4 (1952), 27-30.

3. M. Mori, Contributions to the theory of differentials on open Riemann surfaces, J. Math. Kyoto Univ., 4 (1964), 77-97.

4. B. Rodin, On a paper of M. Watanabe, J. Math. Kyoto Univ., 6 (1967), 393-395.

5. H. L.Royden, On a class of null-bounded Riemann surfaces, Comm. Math. Helv., 34 (1960), 37-51.

6. M. Watanabe, A remark on the Weierstrass points on open Riemann surfaces, J. Math. Kyoto Univ., 5 (1966), 185-192.

Received October 26, 1979 and in revised form March 6, 1980.

CHUKYO UNIVERSITY

101 YAGOTOHONMACHI

SHOWA-KU, NAGOYA

466 JAPAN 


\section{PACIFIC JOURNAL OF MATHEMATICS}

\section{EDITORS}

DONALD BABBITT (Managing Editor)

University of California

Los Angeles, CA 90024

Hugo RossI

University of Utah

Salt Lake City, UT 84112

C. C. MOORE and ANDREW OGG

University of California

Berkeley, CA 94720
J. DugundjI

Department of Mathematics

University of Southern California

Los Angeles, CA 90007

R. FINN and J. MILGRAM

Stanford University

Stanford, CA 94305

\section{ASSOCIATE EDITORS}
R. ARENS
E. F. BECKENBACH
B. H. NeUmanN
F. WOLF
K. YosHIDA

\section{SUPPORTING INSTITUTIONS}

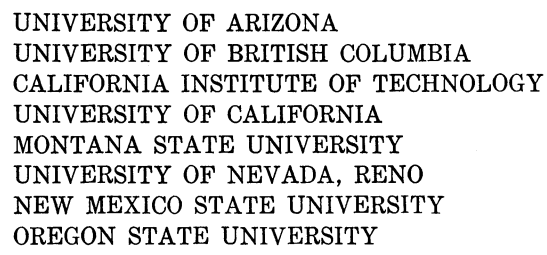

UNIVERSITY OF ARIZONA

UNIVERSITY OF BRITISH COLUMBIA CALIFORNIA INSTITUTE OF TECHNOLOGY

UNIVERSITY OF CALIFORNIA

MONTANA STATE UNIVERSITY

UNIVERSITY OF NEVADA, RENO

NEW MEXICO STATE UNIVERSITY OREGON STATE UNIVERSITY

\author{
UNIVERSITY OF OREGON \\ UNIVERSITY OF SOUTHERN CALIFORNIA \\ STANFORD UNIVERSITY \\ UNIVERSITY OF HAWAII \\ UNIVERSITY OF TOKYO \\ UNIVERSITY OF UTAH \\ WASHINGTON STATE UNIVERSITY \\ UNIVERSITY OF WASHINGTON
}

The Supporting Institutions listed above contribute to the cost of publication of this Journal, but they are not owners or publishers and have no responsibility for its content or policies.

Mathematical papers intended for publication in the Pacific Journal of Mathematics should be in typed form or offset-reproduced, (not dittoed), double spaced with large margins. Please do not use built up fractions in the text of the manuscript. However, you may use them in the displayed equations. Underline Greek letters in red, German in green, and script in blue. The first paragraph or two must be capable of being used separately as a synopsis of the entire paper. Please propose a heading for the odd numbered pages of less than 35 characters. Manuscripts, in triplicate, may be sent to any one of the editors. Please classify according to the scheme of Math. Reviews, Index to Vol. 39. Supply name and address of author to whom proofs should be sent. All other communications should be addressed to the managing editor, or Elaine Barth, University of California, Los Angeles, California, 90024.

50 reprints to each author are provided free for each article, only if page charges have been substantially paid. Additional copies may be obtained at cost in multiples of 50 .

The Pacific Journal of Mathematics is issued monthly as of January 1966. Regular subscription rate: $\$ 102.00$ a year (6 Vols., 12 issues). Special rate: $\$ 51.00$ a year to individual members of supporting institutions.

Subscriptions, orders for numbers issued in the last three calendar years, and changes of address shoud be sent to Pacific Journal of Mathematics, P.O. Box 969, Carmel Valley, CA 93924, U.S.A. Old back numbers obtainable from Kraus Per!odicals Co., Route 100, Millwood, NY 10546.

\section{PUBLISHED BY PACIFIC JOURNAL OF MATHEMATICS, A NON-PROFIT CORPORATION}

Printed at Kokusai Bunken Insatsusha (International Academic Printing Co., Ltd.). 8-8, 3-chome, Takadanobaba, Shinjuku-ku, Tokyo 160, Japan.

Copyright (C) 1981 by Pacific Jounal of Mathematics Manufactured and first issued in Japan 


\section{Pacific Journal of Mathematics}

Vol. 94, No. $2 \quad$ June, 1981

Thomas E. Armstrong and William David Sudderth, Nearly strategic

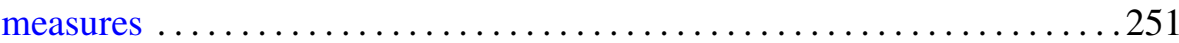

John J. Buoni, Artatrana Dash and Bhushan L. Wadhwa, Joint Browder

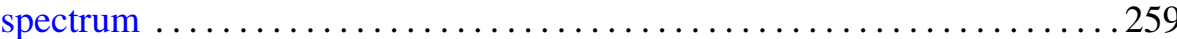

Jack Paul Diamond, Hypergeometric series with a $p$-adic variable . .......265

Raymond Frank Dickman, Jack Ray Porter and Leonard Rubin,

Completely regular absolutes and projective objects ............ 277

James Kenneth Finch, On the local spectrum and the adjoint ........... 297

Benno Fuchssteiner, An abstract disintegration theorem ............ 303

Leon Gerber, The volume cut off a simplex by a half-space $\ldots \ldots \ldots \ldots 311$

Irving Leonard Glicksberg, An application of Wermer's subharmonicity

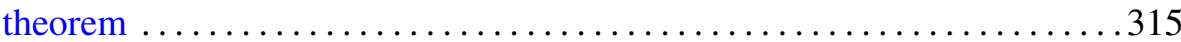

William Goldman, Two examples of affine manifolds ............... 327

Yukio Hirashita, On the Weierstrass points on open Riemann surfaces .....331

Darrell Conley Kent, A note on regular Cauchy spaces ............. 333

Abel Klein and Lawrence J. Landau, Periodic Gaussian

Osterwalder-Schrader positive processes and the two-sided Markov

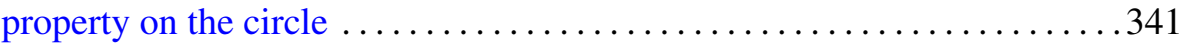

Brenda MacGibbon, $\mathscr{K}$-Borelian embeddings and images of Hausdorff

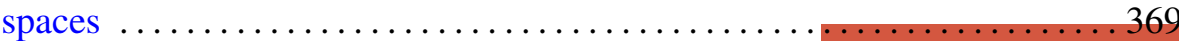

John R. Myers, Homology 3-spheres which admit no PL involutions . . . . . 379

Boon-Hua Ong, Invariant subspace lattices for a class of operators . . . . . 385

Chull Park, Representations of Gaussian processes by Wiener processes . . . 407

Lesley Millman Sibner and Robert Jules Sibner, A sub-elliptic estimate

for a class of invariantly defined elliptic systems $\ldots \ldots \ldots \ldots \ldots \ldots .417$

Justin R. Smith, Complements of codimension-two submanifolds. III.

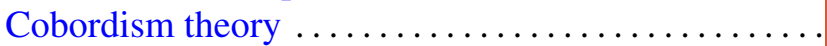

William Albert Roderick Weiss, Small Dowker spaces

David J. Winter, Cartan subalgebras of a Lie algebra and its ideals. II ... 